Article

\title{
Lactiplantibacillus plantarum subsp. plantarum and Fructooligosaccharides Combination Inhibits the Growth, Adhesion, Invasion, and Virulence of Listeria monocytogenes
}

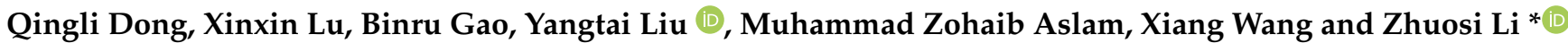

check for

updates

Citation: Dong, Q.; Lu, X.; Gao, B.; Liu, Y.; Aslam, M.Z.; Wang, X.; Li, Z. Lactiplantibacillus plantarum subsp. plantarum and Fructooligosaccharides Combination Inhibits the Growth, Adhesion, Invasion, and Virulence of Listeria monocytogenes. Foods 2022, 11, 170. https://doi.org/10.3390/ foods 11020170

Academic Editor: Andreas

Kimon Karatzas

Received: 30 November 2021

Accepted: 7 January 2022

Published: 10 January 2022

Publisher's Note: MDPI stays neutral with regard to jurisdictional claims in published maps and institutional affiliations.

Copyright: (C) 2022 by the authors. Licensee MDPI, Basel, Switzerland. This article is an open access article distributed under the terms and conditions of the Creative Commons Attribution (CC BY) license (https:// creativecommons.org/licenses/by/ $4.0 /)$.
School of Health Science and Engineering, University of Shanghai for Science and Technology, Shanghai 200093, China; dongqingli@126.com (Q.D.); luxin_xin@163.com (X.L.); gao_binru@163.com (B.G.); usstlyt@163.com (Y.L.); zohaib.aslam.000@gmail.com (M.Z.A.); xiang.wang@usst.edu.cn (X.W.)

* Correspondence: lizhuosi@usst.edu.cn

\begin{abstract}
Listeria monocytogenes is a foodborne pathogen responsible for many food outbreaks worldwide. This study aimed to investigate the single and combined effect of fructooligosaccharides (FOS) and Lactiplantibacillus plantarum subsp. plantarum CICC 6257 (L. plantarum) on the growth, adhesion, invasion, and virulence of gene expressions of Listeria monocytogenes 19112 serotype 4b (L. monocytogenes). Results showed that $L$. plantarum combined with $2 \%$ and $4 \%(w / v)$ FOS significantly $(p<0.05)$ inhibited the growth of L. monocytogenes (3-3.5 $\log _{10} \mathrm{CFU} / \mathrm{mL}$ reduction) at the incubation temperature of $10{ }^{\circ} \mathrm{C}$ and $25^{\circ} \mathrm{C}$. Under the same combination condition, the invasion rates of $L$. monocytogenes to Caco-2 and BeWo cells were reduced more than $90 \%$ compared to the result of the untreated group. After L. plantarum was combined with the $2 \%$ and $4 \%(w / v)$ FOS treatment, the gene expression of actin-based motility, sigma factor, internalin A, internalin B, positive regulatory factor A, and listeriolysin O significantly $(p<0.05)$ were reduced over $91 \%, 77 \%, 92 \%, 89 \%, 79 \%$, and $79 \%$ compared to the result of the untreated group, respectively. The inhibition level of the L. plantarum and FOS combination against L. monocytogenes was higher than that of FOS or L. plantarum alone. Overall, these results indicated that the L. plantarum and FOS combination might be an effective formula against L. monocytogenes.
\end{abstract}

Keywords: Listeria monocytogenes; fructooligosaccharide; Lactiplantibacillus plantarum subsp. plantarum; human cells; gene expression

\section{Introduction}

Listeria monocytogenes is a foodborne pathogen that causes a severely invasive disease called listeriosis. It can infect healthy individuals, but it most commonly affects immunocompromised individuals, pregnant women, newborns, and the elderly [1]. L. monocytogenes is ubiquitous in the environment and is resistant to environmental stresses, such as low temperature, low acid, and high osmolarity concentrations [2]. Due to these features, $L$. monocytogenes is considered a major concern for the food industry. The largest outbreak of listeriosis was reported in South Africa with the consumption of polony (ready-to-eat processed meat) in 2017. From 11 June 2017 to 7 April 2018, a staggering total of 937 cases were identified in that outbreak, of which 193 (27\%) died, 465 (50\%) were associated with pregnancy, and 406 of the pregnancy-associated cases (87\%) occurred in newborn infections [3]. Although the infection rate per year is not high (such as in 2019, the European Union notification rate of 0.46 cases per 100,000 population was reported), the lethality is very high $(20-30 \%)$ [4]. Therefore, it is necessary to strengthen the control of L. monocytogenes in foods.

In recent years, many chemical, physical, and biological technologies have been used as practical approaches for controlling L. monocytogenes in foods [4]. According to the International Scientific Association of Probiotics and Prebiotics (ISAPP), the definition of 
probiotics is "live micro-organisms benefiting the host" [5]. Among those technologies against $L$. monocytogenes, probiotics and their metabolites in foods are considered an effective biological control method that has drawn much attention from the scientific community. Several studies have reported that probiotics can inhibit the growth of L. monocytogenes [5-7]. Kamiloeglu et al. reported that the L. monocytogenes concentration decreased by $274 \log _{10}$ $\mathrm{CFU} / \mathrm{g}$ in the presence of Lactiplantibacillus plantarum S50 in fermented sausage [8]. Our previous study has also verified that Lactiplantibacillus plantarum subsp. plantarum CICC 6257 (L. plantarum) could effectively decrease the concentration of L. monocytogenes in ground pork [9]. Other bacteriocin-producing strains of lactic acid bacteria, including Lactococcus lactis ssp. lactis, have been found with a similar effect on L. monocytogenes (decreased by $2-3 \log _{10} \mathrm{CFU} / \mathrm{g}$ ) in different types of foods [10-12]. These antibacterial properties of probiotics on L. monocytogenes are mainly attributed to the production of antibacterial substances, such as bacteriocins, organic acids (lactic and acetic acid), hydrogen peroxide, and nutritional competition between probiotics and L. monocytogenes [12-14].

Many studies have reported that a combination of technologies and approaches (called hurdle technology) is more effective for controlling L. monocytogenes than single technology $[15,16]$. Prebiotics are "components that are selectively utilized by host microorganisms to confer a health benefit" according to ISAPP [17]. Based on the hurdle technology, the combination of probiotics and prebiotics has been reported to control the growth of enteric bacterial pathogens in vivo $[18,19]$. This phenomenon might be called competition enhancement, i.e., specific nutrients are given to symbiotic microorganisms in the same ecological niche, to better control the growth of pathogenic bacteria [20,21]. Fructooligosaccharides (FOS) are generally regarded as safe (GRAS) for human consumption [22], and a dose of $4 \sim 15 \mathrm{~g}$ /day given to healthy subjects [23] or patients with type 2 diabetes [22] does not show a side effect. FOS are present naturally in several fruits and vegetables [24], and is the most extensively studied prebiotic [25]. FOS could selectively stimulate Lactobacillus spp. or Bifidobacterium spp. [26-28], and inhibit Escherichia coli in vivo [29]. In vitro, FOS were found to inhibit the growth of Pseudomonas aeruginosa [30] and Salmonella typhimurium [31] in the culture medium, and reduce the adhesion of Clostridium difficile [32] and some anaerobic pathogens [33] to host cells. The combined treatment of Lactobacillus rhamnosus NCDC 298 and FOS prevented the adhesion of enterotoxigenic E. coli to HT-29 cells [34]. Combined Lactobacillus brevis KU200019 and FOS inhibited pathogen adherence to HT-29 cells [35]. Thus, in this study, we use FOS and L. plantarum as a hurdle technology to explore its possible inhibitory effect on $L$. monocytogenes.

After ingesting contaminated food, L. monocytogenes could cross the intestinal epithelial barrier into the lamina propria, disseminate into blood, and even cross the blood-brain barrier or the placental barrier, which are the tightest barriers of the human body [36]. The adhesion and invasion ability of the pathogen to the host cell is an important and useful approach to judge the effects of bacteriostatic measures [37]. Specifically, the mild biological bacteriostatic method often could not eliminate bacteria; thus, it becomes more critical to evaluate the virulence of bacteria in vitro or in vivo after biological control. Caco-2 cells $[38,39]$ and BeWo cells $[40,41]$, as the most commonly used representatives of intestinal and fetoplacental barrier models, respectively, were used to evaluate the adhesion and invasion of foodborne pathogens in vitro. It has been proven that L. monocytogenes can adhere and invade Caco-2 cells [42,43] and BeWo cells [44,45].

L. monocytogenes is a facultative intracellular pathogen that infects phagocytes and normally non-phagocytic cells, such as epithelial cells [46]. It can resist the adverse environment of the gastrointestinal tract, survive, and divide in the cytosol of host cells, and spread from one cell to another [46-48]. These processes occur in several stages and require an elaborate network of virulent factors, among which sigma factor $(\operatorname{sig} B)$, positive regulatory factor A ( prfA), internalin A (inlA), internalin B (inlB), actin-based motility (actA), and listeriolysin $\mathrm{O}(h l y)$ are considered the principal determinants. When $L$. monocytogenes infects host cells, sigB is involved in the stress response, regulating many stress-related genes [49]. The inlA and inlB play core roles in internalizing L. monocytogenes into host cells [50]. After 
internalization, L. monocytogenes produces listeriolysin $\mathrm{O}(h l y)$, which mediates the escape of L. monocytogenes from phagosomes [51]. Meanwhile, act $A$ is involved in the adhesion and intracellular motility of L. monocytogenes [52]. As mentioned above, the action of virulence factors contributes to L. monocytogenes infection. To better prove the effect of FOS and $L$. plantarum, the virulence factors of L. monocytogenes should also be evaluated.

Therefore, in this study, we tried to explore the single or joint effect of L. plantarum and FOS on L. monocytogenes potential growth, its adhesion and invasion to Caco-2 and BeWo cells, and its virulence genes expression.

\section{Materials and Methods}

\subsection{Bacterial Strains and Culture Preparation}

The reference strains L. monocytogenes 19112 (serotype 4b) and the strain L. plantarum CICC 6257 were obtained from the China Center of Industrial Culture Collection Beijing (CICC, http: / / www.china-cicc.org/, accessed on 11 September 2021). Frozen stocks of $L$. monocytogenes were maintained in tryptone soy yeast extract broth (TSB-YE; Beijing Land Bridge Technology Co., Ltd., Beijing, China) with $50 \%$ glycerol at $-80{ }^{\circ} \mathrm{C}$. Working stocks of L. monocytogenes were stored at $4{ }^{\circ} \mathrm{C}$ on tryptone soy agar with $0.6 \%$ yeast extract (TSA-YE; Beijing Land Bridge Technology Co., Ltd., Beijing, China) and were renewed monthly. Frozen stocks of L. plantarum were maintained in MRS broth (MRSB, Hopebio, Qingdao, China) with $50 \%$ glycerol at $-80^{\circ} \mathrm{C}$. Working stocks of L. plantarum were stored at $4{ }^{\circ} \mathrm{C}$ on MRS agar (MRSA, Hopebio, Qingdao, China) and were renewed monthly. For activation, a single colony of L. monocytogenes and L. plantarum were separately transferred from TSA-YE and MRS to the brain heart infusion broth (BHI, Beijing Luqiao Co., Beijing, China), and aerobically incubated at $37^{\circ} \mathrm{C}$ for $16 \sim 18 \mathrm{~h}$. After that, the L. monocytogenes and L. plantarum cultures were centrifuged at $21,127 \times \mathrm{g} / \mathrm{min}$ for $10 \mathrm{~min}\left(4^{\circ} \mathrm{C}\right)$, washed thrice, and then resuspended in $0.85 \%$ sterile saline solution (SSS, $\mathrm{pH}=7.2$ ) to $10^{8}-10^{9} \mathrm{CFU} / \mathrm{mL}$ inoculums.

\subsection{Sample Preparation and Inoculation}

It is reported that $2 \%$ FOS added in yogurt showed an inhibitory effect on L. monocytogenes [35], and did not show adverse sensory properties [53]. We found that less than $1 \%$ FOS treatment did not show an inhibitory effect on L. monocytogenes. Thus, based on previous reports and our preliminary studies, 1 4\% FOS was used for evaluating the effect of FOS. L. monocytogenes was diluted to inoculate $\left(10^{2}-10^{3} \mathrm{CFU} / \mathrm{mL}\right)$ in BHI with or without 1 4\% (w/v) FOS (Shanghai yuanye Bio-Technology Co., Ltd., CAS: 308066-66-2, purity 95\%, Shanghai, China) and incubated at $10{ }^{\circ} \mathrm{C}$ and $25^{\circ} \mathrm{C}$. At $10{ }^{\circ} \mathrm{C}$, L. monocytogenes is in the growth phase during the first 10 days of incubation, thus the sampling was performed once a day; while after 10 days, the L. monocytogenes is in a stationary phase, so the sampling was performed every two days. Like $10^{\circ} \mathrm{C}$, at $25^{\circ} \mathrm{C}$ every four hours before $24 \mathrm{~h}$ of incubation and a longer interval after $24 \mathrm{~h}$ were set as the sampling timelines. Thus, sampling was performed on days $0,2,3,4,5,6,7,8,10,12,14,16$, and 18 at $10{ }^{\circ} \mathrm{C}$, and on $0,5,9,13,17,21$, 27 , and $45 \mathrm{~h}$ at $25^{\circ} \mathrm{C}$ until inhibitory effects were observed. The apparent inhibitory effect of the FOS alone treatment was observed after 18 days at $10^{\circ} \mathrm{C}$ and $45 \mathrm{~h}$ at $25^{\circ} \mathrm{C}$; thus, this incubation condition was used in the subsequent experiment.

To evaluate the combined effect of L. plantarum and FOS, both L. monocytogenes and L. plantarum were diluted to $10^{2}-10^{3} \mathrm{CFU} / \mathrm{mL}$ in BHI with or without $1 \sim 4 \%(w / v)$ FOS and incubated for 18 days at $10^{\circ} \mathrm{C}$ and $45 \mathrm{~h}$ at $25^{\circ} \mathrm{C}$, respectively. Thus, the treatment of $L$. monocytogenes was divided into eight groups: the untreated group, 1\% FOS, 2\% FOS, 4\% FOS, L. plantarum alone, L. plantarum $+1 \%$ FOS, L. plantarum $+2 \%$ FOS, and L. plantarum + $4 \%$ FOS. The L. monocytogenes and L. plantarum concentrations were determined by plating on the PALCAM (Polymyxin Acriflavin Lithium-chloride Ceftazidime Esculin Mannitol) agar base with selective supplement (PALCAM, Qingdao Haibo Co., Ltd., Qingdao, China) and MRSA, respectively, followed by aerobic incubation at $37^{\circ} \mathrm{C}$ for $24 \mathrm{~h}$ [9]. The counts of colonies were expressed as $\log _{10} \mathrm{CFU} / \mathrm{mL}$. 


\subsection{In Vitro Virulence Assays}

The human intestinal epithelial Caco-2 cells (FH0029, passage 10 20) were obtained from FuHeng Biology (Shanghai, China) and cultured in Dulbecco's modified Eagle medium (DMEM) containing 10\% fetal bovine serum (FBS), 1.25\% L-glutamine, and 1.25\% penicillin-stretomycin solution in a humidified atmosphere of $95 \%$ air and $5 \% \mathrm{CO}_{2}$ at $37{ }^{\circ} \mathrm{C}$. The choriocarcinoma cell line BeWo (FH0248, passage 5 10) obtained from FuHeng Biology were cultured in Ham's F12 medium Cellgro (www.cellgro.com, accessed on 11 September 2021) with $10 \%$ FBS, and $1.25 \%$ penicillin-streptomycin solution in a humidified atmosphere of $95 \%$ air and $5 \% \mathrm{CO}_{2}$ at $37^{\circ} \mathrm{C}$.

The adhesion and invasion of L. monocytogenes to Caco- 2 cell monolayers were assessed as described by the previous study [37,54]. Briefly, Caco-2 cells were plated into 12-well tissue culture plates (Greiner Bio-One, Frickenhausen, Germany) in DMEM with 10\% FBS and $1.25 \%$ penicillin-streptomycin solution and incubated until $90 \%$ confluence.

L. monocytogenes with and without FOS and L. plantarum, were cultivated at $10{ }^{\circ} \mathrm{C}$ for 12 days and $25^{\circ} \mathrm{C}$ for $40 \mathrm{~h}$. These bacterial cultures were centrifuged ( $\left.5282 \times \mathrm{g} / \mathrm{min}, 5 \mathrm{~min}\right)$, and resuspended in pre-heated DMEM without FBS and penicillin-stretomycin solution at $37^{\circ} \mathrm{C}$. The initial L. monocytogenes counting was performed by plating on PALCAM and denoted as $N_{0}$. For adhesion, Caco- 2 and BeWo cell monolayers were infected with $L$. monocytogenes cultures described above for $2 \mathrm{~h}$ at $37^{\circ} \mathrm{C}$. Caco- 2 and BeWo cells were then washed twice with phosphate-buffered saline (PBS) and lysed with $1 \mathrm{~mL}$ of cold $0.1 \%$ Triton X-100 (Applichem, Darmstadt, Germany) for $5 \mathrm{~min}$. After adhesion, the L. monocytogenes counting was performed by plating on PALCAM and denoted as $N_{1}$.

For the invasion assay, Caco- 2 and BeWo cell monolayers were infected with L. monocytogenes cultures for $2 \mathrm{~h}$ at $37^{\circ} \mathrm{C}$ as described above. Cells were then washed twice with PBS, incubated in DMEM containing $0.1 \%$ FBS and $100 \mu \mathrm{g} / \mathrm{mL}$ penicillin-streptomycin for $45 \mathrm{~min}$ and lysed with $1 \mathrm{~mL}$ of cold $0.1 \%$ Triton X-100 for $5 \mathrm{~min}$. After adhesion, the $L$. monocytogenes counting was performed by plating on PALCAM and denoted as $N_{2}$. All assays were independently repeated six times. Most previous reports used $1-2 \mathrm{~h}$ to detect the in vitro adhesion and invasion [55], so we used 1, 1.5, and $2 \mathrm{~h}$ for evaluation, and $2 \mathrm{~h}$ was the shortest time to detect the difference among different treatment groups.

The adhesion and invasion efficiencies were calculated as the following equations:

$$
\begin{gathered}
\text { Adhesion efficiency }=N_{1} / N_{0} \times 100 \% \\
\text { Invasion efficiency }=N_{2} / N_{0} \times 100 \%
\end{gathered}
$$

While $N_{0}$ is the number of L. monocytogenes in the initial inoculum; $N_{1}$ is the number of L. monocytogenes that adhered to cells; and $N_{2}$ is the number of L. monocytogenes that invaded into cells.

\subsection{Analysis of Virulence Factors of L. monocytogenes by Quantitative Real-Time PCR (qRT-PCR)}

L. monocytogenes with and without treatment with FOS or L. plantarum, cultivated at $10^{\circ} \mathrm{C}$ for 12 days and $25^{\circ} \mathrm{C}$ for $40 \mathrm{~h}$, was separately applied for total RNA extraction. The total RNA was extracted using the Bacteria Total RNA Isolation Kit (Sangon Biotech, Shanghai, China) based on a standard protocol and quantified by a NanoDrop 2000 (Thermo Fisher Scientific, Waltham, MA, USA). Subsequently, the residual DNA was removed from the total RNA and the cDNA was synthesized, using Hiscript ${ }^{\circledR}$ II Reverse Transcriptase Kit (Vazyme Biotech Co., Ltd., Nanjing, China). Primers used in this study were designed by Zilelidou et al. [55], synthesized by Sangon Biotech Co., Ltd. (Shanghai, China), and listed in Table 1. An analysis of qRT-PCR was performed using the ABI 7900HT real-time PCR system (Applied Biosystems, Foster, USA) in $20 \mu \mathrm{L}$ reaction solution, including $1.2 \mu \mathrm{L}$ cDNA template (ca. $120 \mathrm{ng}$ ), total $10 \mu \mathrm{L}$ Taq Pro Universal SYBR qPCR Master Mix $(2 \times)$, $8 \mu \mathrm{L}$ nuclease-free water, and $0.8 \mu \mathrm{L}$ primer $(10 \mu \mathrm{M})$. The intergenic spacers $r p o B$ were used as housekeeping genes; $\operatorname{prf} A, \operatorname{sig} B, h l y, \operatorname{act} A, \operatorname{inl} A$, and $i n l B$ as virulence factors of L. monocytogenes were evaluated as well. The amplification program for RT-qPCR was 
as follows: 1 cycle at $95^{\circ} \mathrm{C}$ for $30 \mathrm{~s}, 40$ cycles at $95^{\circ} \mathrm{C}$ for $5 \mathrm{~s}$, and $60{ }^{\circ} \mathrm{C}$ for $30 \mathrm{~s}$; a melt curve program, $95^{\circ} \mathrm{C}$ for $10 \mathrm{~s}, 65^{\circ} \mathrm{C}$ for $60 \mathrm{~s}$, and $97^{\circ} \mathrm{C}$ for $1 \mathrm{~s}$, was added to evaluate the specificity of the RT-PCR products. The relative transcription level of the five virulent genes, $\operatorname{sig} B$, inlA, inlB, hly, and $\operatorname{prf} A$, was calculated using the $2^{-\Delta \Delta \mathrm{Ct}}$ method [56].

Table 1. The primer sequences used for RT-qPCR analyses [55].

\begin{tabular}{|c|c|c|}
\hline Gene & Primer Sequences & Length (bp) \\
\hline rров & $\begin{array}{l}\text { F: TCGTCGTCTTCGTTCTGTTGR: } \\
\text { GTTCGCCAAGTGGATTTGTT }\end{array}$ & 221 \\
\hline inlA & $\begin{array}{l}\text { F: ATAGGCACATTGGCGAGTTT } \\
\text { R: GTGCGGTTAAACCTGCTAGG }\end{array}$ & 160 \\
\hline inlB & $\begin{array}{c}\text { F: AAGCAMGATTTCATGGGAGAGT } \\
\text { R: TTACCGTTCCATCAACATCATAACTT }\end{array}$ & 78 \\
\hline hly & $\begin{array}{c}\text { F: CTTTTAACCGGGAAACACCA } \\
\text { R: TCTTGCGTTACCTGGCAAA }\end{array}$ & 302 \\
\hline $\operatorname{act} A$ & $\begin{array}{l}\text { F: CGGGTAAATGGGTACGTGAT } \\
\text { R: TGGTCAATTAACCCTGCACTT }\end{array}$ & 85 \\
\hline $\operatorname{prfA}$ & $\begin{array}{l}\text { F: CGGGAAGCTTGGCTCTATTTG } \\
\text { R: GCTAACAGCTGAGCTATGTGC }\end{array}$ & 150 \\
\hline $\operatorname{sig} B$ & $\begin{array}{l}\text { F: TCATCGGTGTCACGGAAGAA } \\
\text { R: TGACGTTGGATTCTAGACAC }\end{array}$ & 310 \\
\hline
\end{tabular}

\subsection{Statistical Analysis}

All assays were performed in at least six biological independent experiments, and the results were shown as mean values with standard deviations. The ANOVA analysis (SPSS 18.0 statistical software, IBM Corporation, Armonk, NY, USA) followed by a Tukey test at $95 \%$ confidence limits were applied to determine the difference in the growth, the ability of adhesion and invasion to the cell, and the relative expression of the virulence genes of L. monocytogenes.

\section{Results}

\subsection{Effectiveness of FOS Treatment against L. monocytogenes in BHI}

The L. monocytogenes concentration in the untreated group increased to day 10 at $10{ }^{\circ} \mathrm{C}$, and an increasing trend was observed on days 16-18 (Figure 1a). After 16 days, $L$. monocytogenes concentrations in the FOS treatment groups were significantly decreased compared with the untreated group at $10{ }^{\circ} \mathrm{C}$ (Figure 1a). Among them, L. monocytogenes concentrations in the $1 \%, 2 \%$, and $4 \%$ FOS groups showed the reduction of 1,1 , and $2 \log _{10}$ $\mathrm{CFU} / \mathrm{mL}$ compared with the untreated group on day 18 at $10{ }^{\circ} \mathrm{C}$, respectively (Figure 1a). After $27 \mathrm{~h}$ at $25^{\circ} \mathrm{C}$, L. monocytogenes concentrations in the $2 \%$ and $4 \%$ FOS treatment groups significantly decreased compared with the untreated group at $25^{\circ} \mathrm{C}$ (Figure $1 \mathrm{~b}$ ). Among them, L. monocytogenes concentrations in the $1 \%, 2 \%$, and $4 \%$ FOS groups represent the reduction of $0.1,0.8$, and $1.5 \log _{10} \mathrm{CFU} / \mathrm{mL}$ compared with the untreated group at $45 \mathrm{~h}$ at $25{ }^{\circ} \mathrm{C}$ (Figure $1 \mathrm{~b}$ ). It was observed that FOS treatments against L. monocytogenes were more effective at $10^{\circ} \mathrm{C}$ as compared to $25^{\circ} \mathrm{C}$ (Figure $1 \mathrm{a}, \mathrm{b}$ ).

\subsection{Effectiveness of L. plantarum and FOS Combination Treatment against L. monocytogenes in $B H I$}

The effect of the L. plantarum and FOS combination on the growth of L. monocytogenes at $10{ }^{\circ} \mathrm{C}$ and $25^{\circ} \mathrm{C}$ was investigated. When L. monocytogenes was incubated with L. plantarum at $10^{\circ} \mathrm{C}$, the growth of L. monocytogenes was significantly $(p<0.05)$ reduced after 10 days compared with the untreated group (Figure 2a). The L. plantarum and FOS combination treatment showed a more obvious inhibitory effect than the L. plantarum alone or FOS alone treatment (Figure 2a). L. monocytogenes concentrations in L. plantarum, L. plantarum $+1 \%$ FOS, L. plantarum $+2 \%$ FOS, and L. plantarum $+4 \%$ FOS groups represented a reduction 
of $2,2.5,3$, and $3 \log _{10} \mathrm{CFU} / \mathrm{mL}$ compared with the untreated group on 18 days at $10{ }^{\circ} \mathrm{C}$ (Figure 2a).

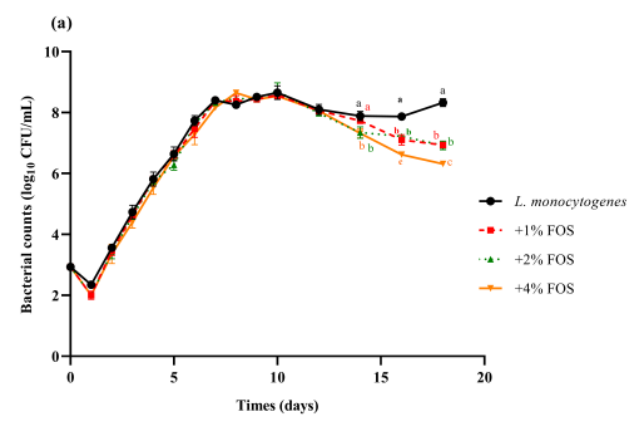

(a)

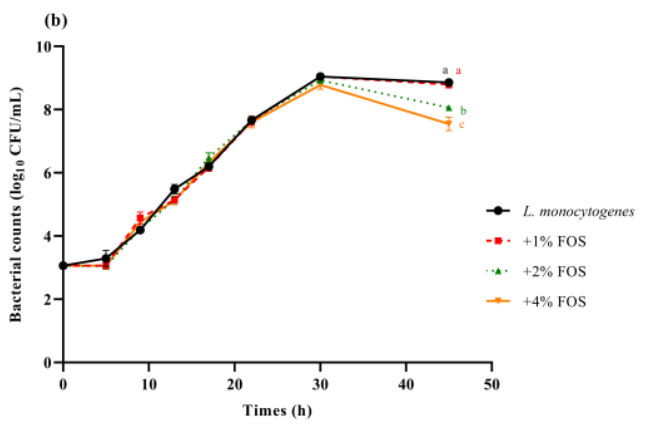

(b)

Figure 1. Growth kinetics of L. monocytogenes with the presence of $1 \%(w / v)$ FOS, $2 \%(w / v)$ FOS, or $4 \%(w / v)$ FOS in BHI at $10{ }^{\circ} \mathrm{C}$ for 18 days (a) and at $25^{\circ} \mathrm{C}$ for $45 \mathrm{~h}(\mathbf{b})$. Data represented as $\log _{10}$ $(\mathrm{CFU} / \mathrm{mL})$ are mean values $\pm \mathrm{SD}$ with $(n=6)$.

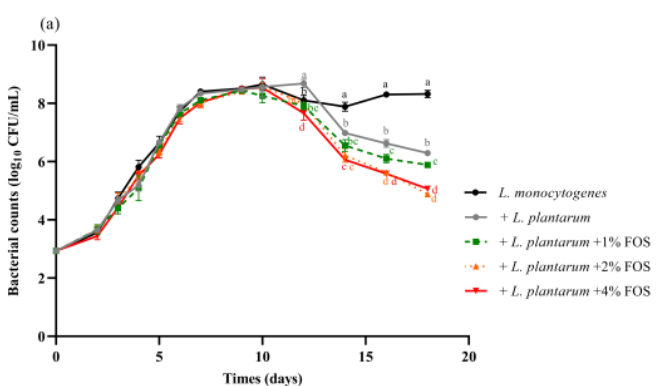

(a)

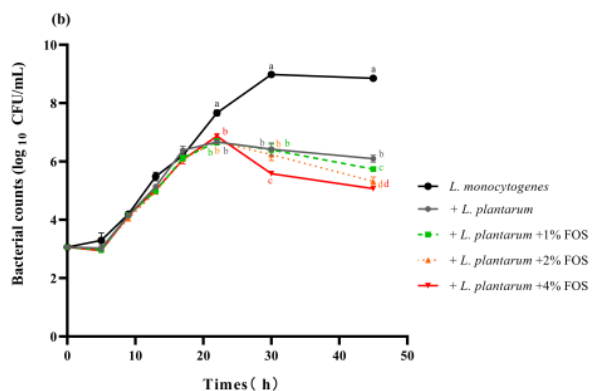

(b)

Figure 2. Growth kinetics of L. monocytogenes on L. plantarum combined with $1 \%(w / v)$ FOS, $2 \%(w / v)$ FOS, or $4 \%(w / v)$ FOS in BHI at $10{ }^{\circ} \mathrm{C}$ for 18 days (a) and at $25^{\circ} \mathrm{C}$ for $45 \mathrm{~h}(\mathbf{b})$. Data represented as $\log _{10}(\mathrm{CFU} / \mathrm{mL})$ are mean values $\pm \mathrm{SD}(n=6)$.

At $25{ }^{\circ} \mathrm{C}$, the addition of L. plantarum significantly $(p<0.05)$ inhibited the growth of $L$. monocytogenes compared with the untreated group after $21 \mathrm{~h}$ of storage (Figure $2 \mathrm{~b}$ ). $L$. monocytogenes concentrations with L. plantarum alone, L. plantarum $+1 \%$ FOS, L. plantarum + $2 \%$ FOS, and L. plantarum $+4 \%$ FOS treatment represented a reduction of $2.5,3,3.5$, and 3.5 $\log _{10} \mathrm{CFU} / \mathrm{mL}$ compared with the untreated group at $45 \mathrm{~h}$ at $25^{\circ} \mathrm{C}$ (Figure 2b). Similarly, the L. plantarum and FOS combination treatment showed a more obviously inhibited effect on the growth of L. monocytogenes than the L. plantarum alone or FOS alone treatment at $25^{\circ} \mathrm{C}$ (Figure $2 b$ ).

\subsection{Ability of Adhesion and Invasion of L. monocytogenes to Caco-2 and BeWo Cells In Vitro}

Then we investigated the single or joint effect of L. plantarum and FOS on in vitro adhesion and invasion of L. monocytogenes to Caco- 2 and BeWo cells. The adhesion and invasion of $L$. monocytogenes were measured after incubation at $10{ }^{\circ} \mathrm{C}$ for 12 days and $25^{\circ} \mathrm{C}$ for $40 \mathrm{~h}$, respectively. At 10 and $25^{\circ} \mathrm{C}$, the adhesion rates of L. monocytogenes to BeWo cells were significantly higher than those of Caco-2 cells in the untreated or FOS treatment groups (Figure $3 \mathrm{a}, \mathrm{b})$. Additionally, the invasion rate of L. monocytogenes to BeWo cells in all eight groups at $25^{\circ} \mathrm{C}$ for $40 \mathrm{~h}$ was higher than that of Caco-2. 


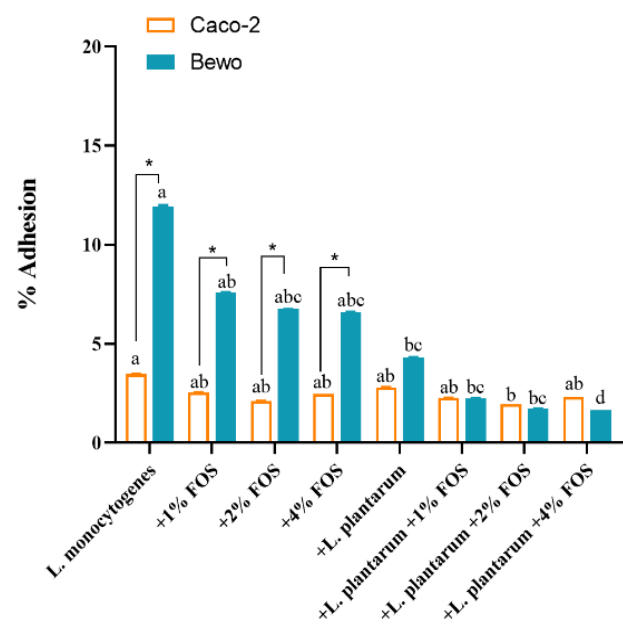

(a)

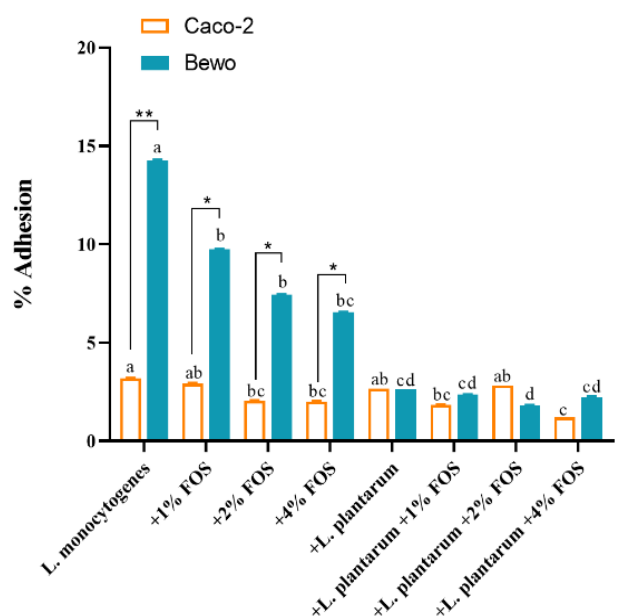

(b)

Figure 3. Adhesion to Caco-2 cells and BeWo cells of L. monocytogenes, grown in BHI at $10{ }^{\circ} \mathrm{C}$ for 12 days (a) or at $25^{\circ} \mathrm{C}$ for $40 \mathrm{~h}(\mathbf{b})$ in different treatment groups: (1) the untreated, (2) $1 \%(w / v)$ FOS, (3) $2 \%(w / v)$ FOS, $(4) 4 \%(w / v)$ FOS, (5) L. plantarum supplementation, (6) L. plantarum $+1 \%(w / v)$ FOS, (7) L. plantarum $+2 \%(w / v)$ FOS, (8) L. plantarum $+4 \%(w / v)$ FOS groups. Values are mean \pm $\mathrm{SD}(n=6)$. Asterisks indicate significant differences between the invasion rate to Caco-2 and BeWo cells, ${ }^{*} p<0.05,{ }^{* *} p<0.01$. Different lowercase letters (a, b, c, and d) indicate significant differences $(p<0.05)$ among treatments for each cell lines.

At $10{ }^{\circ} \mathrm{C}$, for the Caco-2 and BeWo cells, different concentrations of FOS had no significant $(p>0.05)$ inhibitory effect on the adhesion rate of L. monocytogenes compared with the untreated group (Figure 3a). However, the combined treatment of L. plantarum + FOS significantly $(p<0.05)$ reduced the adhesion rate of L. monocytogenes in BeWo cells (Figure 3a). Specifically, the adhesion rate of L. monocytogenes to BeWo cells was the lowest in L. plantarum $+4 \%$ FOS (Figure 3a). The adhesion rate of L. monocytogenes to Caco-2 cells was significantly reduced by the L. plantarum $+2 \%$ FOS treatment compared with the untreated group (Figure 3a). At $25{ }^{\circ} \mathrm{C}$, the adhesion rates of L. monocytogenes to Caco-2 cells were significantly $(p<0.05)$ reduced in the $2 \%$ FOS, $4 \%$ FOS, L. plantarum $+1 \%$ FOS, and L. plantarum $+4 \%$ FOS groups compared with the untreated group (Figure $3 \mathrm{~b}$ ). All treatment conditions significantly reduced the adhesion rates of L. monocytogenes to BeWo cells (Figure $3 b$ ).

At $10{ }^{\circ} \mathrm{C}$, all treatment significantly reduced the invasion rates of L. monocytogenes to BeWo cells. After the combined treatment of L. plantarum and FOS, over $90 \%$ of the invasion levels were reduced compared to the result of the untreated group (Figure $4 \mathrm{a}$ ). At $10{ }^{\circ} \mathrm{C}$, the invasion rates of L. monocytogenes to Caco-2 cells were significantly $(p<0.05)$ reduced in the $4 \%$ FOS, L. plantarum, L. plantarum $+1 \%$ FOS, L. plantarum $+2 \%$ FOS, and L. plantarum + $4 \%$ FOS groups compared with the results of the untreated group (Figure $4 \mathrm{a}$ ). At $25{ }^{\circ} \mathrm{C}$, the invasion rate of L. monocytogenes to Caco-2 were significantly $(p<0.05)$ reduced to less than $0.001 \%$ using treatments of $4 \%$ FOS, L. plantarum, L. plantarum $+1 \%$ FOS, L. plantarum + $2 \%$ FOS, and L. plantarum $+4 \%$ FOS (Figure $4 \mathrm{~b}$ ). For BeWo cells, the L. plantarum addition treatment significantly reduced the invasion rate of L. monocytogenes at $10^{\circ} \mathrm{C}$ (Figure $4 \mathrm{~b}$ ). In addition, at $25{ }^{\circ} \mathrm{C}$ the invasion rates of L. monocytogenes to BeWo cells were significantly higher than those of Caco-2 cells in different treatment groups (Figure 4b); similar results were not found at $10^{\circ} \mathrm{C}$. 


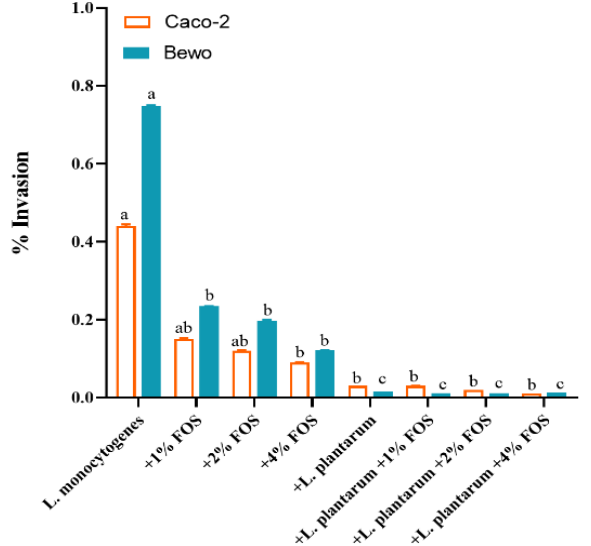

(a)

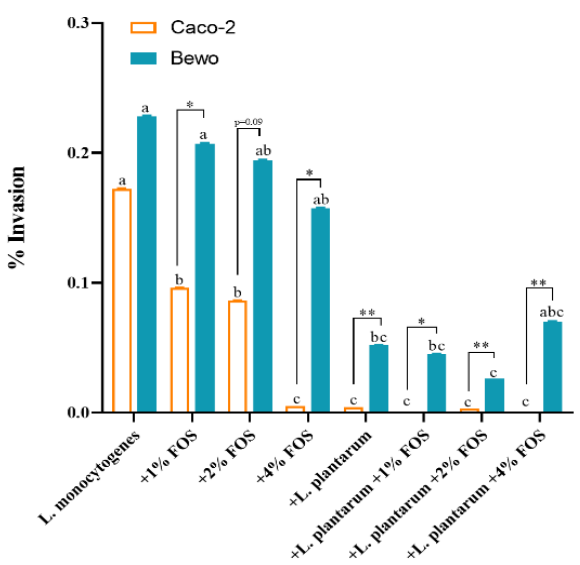

(b)

Figure 4. Invasion to Caco-2 cells and BeWo cells of L. monocytogenes grown in BHI at $10{ }^{\circ} \mathrm{C}$ for 12 days (a) or at $25{ }^{\circ} \mathrm{C}$ for $40 \mathrm{~h}(\mathbf{b})$ in different treatment groups: (1) the untreated, (2) $1 \%(w / v)$ FOS, (3) $2 \%(w / v)$ FOS, (4) $4 \%(w / v)$ FOS, (5) L. plantarum supplementation, (6) L. plantarum $+1 \%(w / v)$ FOS, (7) L. plantarum $+2 \%(w / v)$ FOS, (8) L. plantarum $+4 \%(w / v)$ FOS groups. Values are mean \pm SD $(n=6)$. Asterisks indicate significant differences between the invasion rate to Caco-2 and BeWo cells, ${ }^{*} p<0.05,{ }^{* *} p<0.01$. Different lowercase letters $(\mathrm{a}, \mathrm{b}$, and $\mathrm{c})$ indicate significant differences $(p<0.05)$ among treatments for each cell lines.

\subsection{Virulence Genes Expression of L. monocytogenes}

We investigated the transcriptional profiles of key L. monocytogenes virulence genes associated with invasion and intracellular proliferation into host cells. The expression levels of inlA, inlB, sigB, prfA, hly, and act $A$ in L. monocytogenes at $25^{\circ} \mathrm{C}$ for $40 \mathrm{~h}$ and at $10{ }^{\circ} \mathrm{C}$ for 12 days were determined. At $10{ }^{\circ} \mathrm{C}$ for 12 days, inl $A$, inlB, hly, act $A$, sig $B$, and prfA genes expression of $L$. monocytogenes were significantly decreased by FOS alone, $L$. plantarum alone, and FOS + L. plantarum combined treatment, compared with that of the untreated group (Figure 5). At $10{ }^{\circ} \mathrm{C}$ for 12 days, inlA, hly, and $\operatorname{sig} B$ genes expression of $L$. monocytogenes in the FOS and L. plantarum combination group displayed to be obviously inhibited compared with the FOS or L. plantarum alone treatment groups. In contrast, no significant differences in $i n l B, \operatorname{prf} A$, and $a c t A$ gene expression were observed among FOS alone, L. plantarum alone, and FOS + L. plantarum combination groups (Figure 5). Furthermore, the gene expression of $\operatorname{prf} A$ at $10{ }^{\circ} \mathrm{C}$ with $1 \% \mathrm{FOS}+\mathrm{L}$. plantarum treatment did not show similar results compared with that of $1 \%$ FOS treatment.

At $25^{\circ} \mathrm{C}$ for $40 \mathrm{~h}$, inlA, inlB, hly, sigB, and prfA genes expression of L. monocytogenes were significantly decreased by the FOS, L. plantarum, and FOS + L. plantarum treatment, compared with the results of the untreated group (Figure 6). At $25^{\circ} \mathrm{C}$ for $40 \mathrm{~h}$ compared with the FOS alone treatment, the L. plantarum addition could significantly $(p<0.05)$ reduce the expression of $i n l A$ and $i n l B$ genes. The gene expressions of inlA and inlB in the $L$. plantarum and FOS combination groups were about $90 \%$ lower than that of the untreated group (Figure 6). The expression levels of $h l y, \operatorname{Prf} A$, and $\operatorname{sig} B$ genes in the FOS alone, $L$. plantarum alone, and FOS and L. plantarum combination groups were about $40 \%-85 \%$ lower than that of the untreated group (Figure 6). The expression levels of the act $A$ gene were significantly reduced in all treatment groups except the L. plantarum $+1 \%$ FOS group compared with that of the untreated group (Figure 6). The L. plantarum $+1 \%$ FOS treatment showed an inhibitory effect on the growth, adhesion, and invasion of L. monocytogenes, but a poor inhibitory effect on $a c t A$ and Pref $A$ gene expressions, compared with the $1 \%$ FOS treatment. The FOS was freshly prepared before each use, and the other concentration of FOS treatment showed an inhibitory effect (Figure 6). Thus, we speculated that the addition of L. plantarum may affect the action of $1 \%$ FOS, extended processing time will be helpful to verify our hypothesis in the future. 

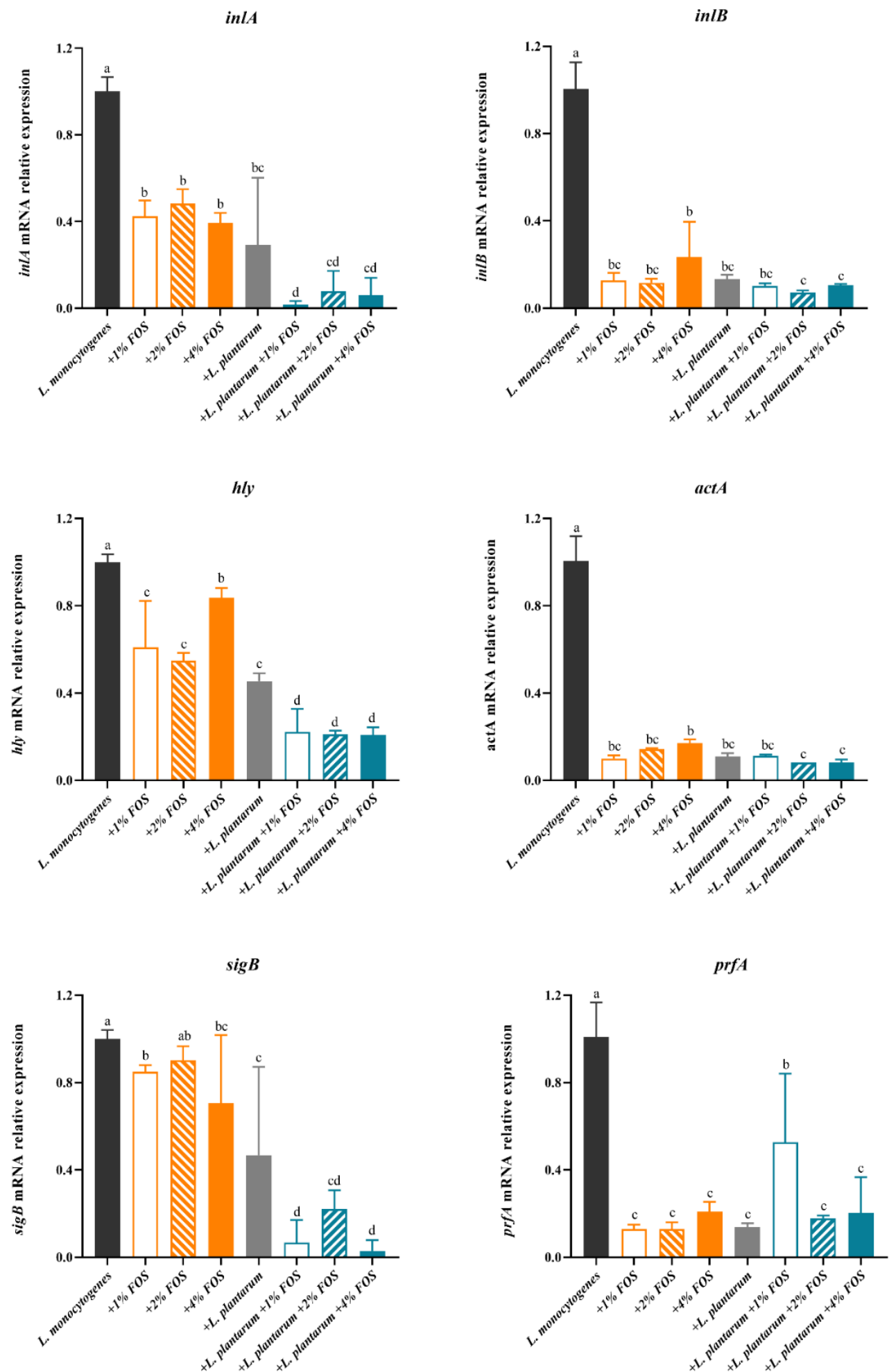

Figure 5. Relative expression levels of virulence genes of L. monocytogenes in BHI at $10{ }^{\circ} \mathrm{C}$ for 12 days in different treatment groups: (1) the untreated group (black bar), (2) 1\% (w/v) FOS (orange hollow bars), (3) 2\% (w/v) FOS (slash orange bars), (4) 4\% (w/v) FOS (orange bars), (5) L. plantarum supplementation group (dark gray bars), (6) L. plantarum $+1 \%(w / v)$ FOS (blue hollow bars), (7) $L$. plantarum $+2 \%(w / v)$ FOS (slash blue bars), (8) L. plantarum $+4 \%(w / v)$ FOS (blue bars). Values are mean $\pm \mathrm{SD}(n=6)$. At each temperature, different lowercase letters $(\mathrm{a}, \mathrm{b}, \mathrm{c}$, and $\mathrm{d})$ indicate significant differences $(p<0.05)$ among treatments. 

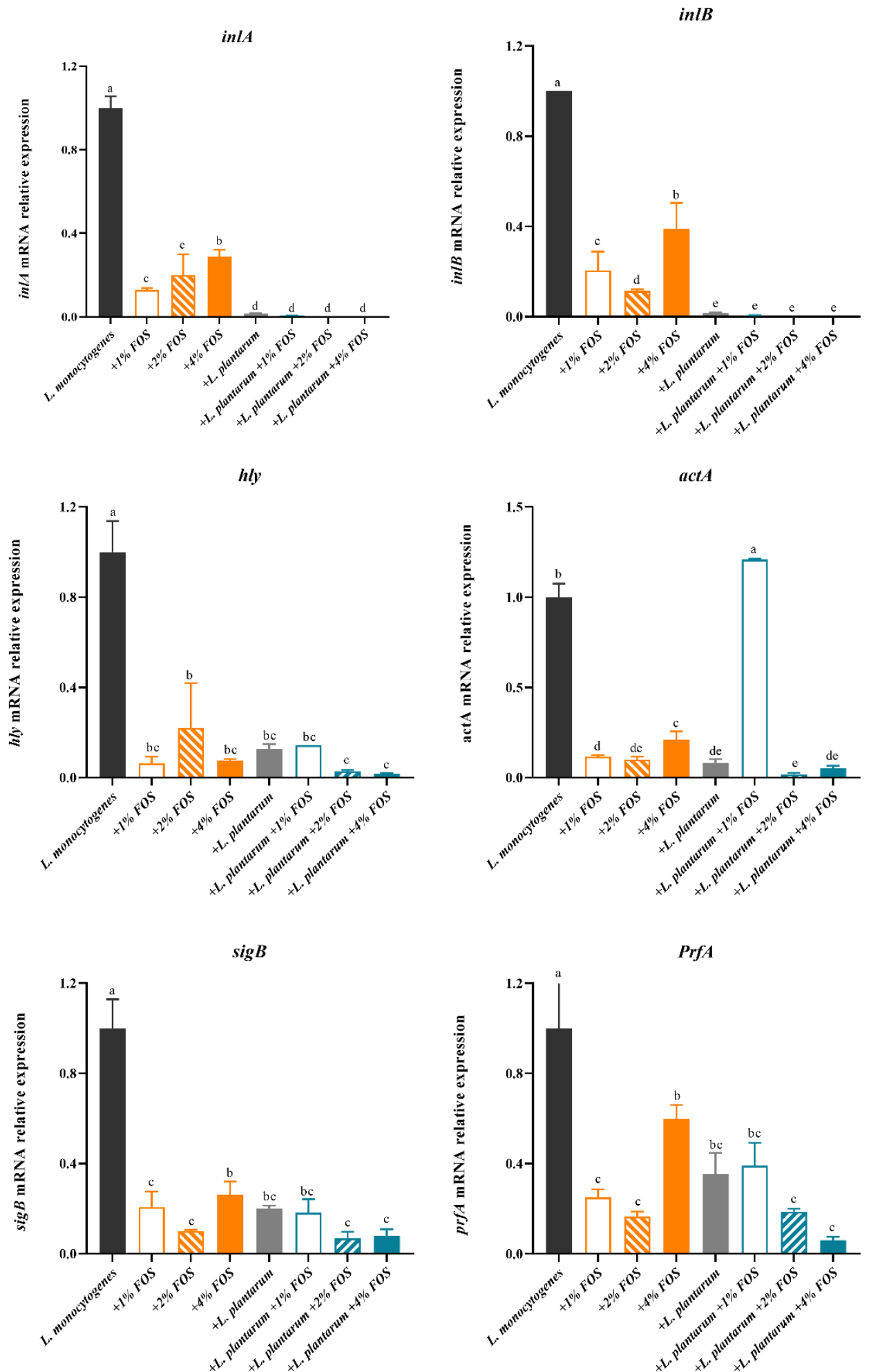

Figure 6. Relative expression levels of virulence genes of L. monocytogenes in $\mathrm{BHI}$ at $25^{\circ} \mathrm{C}$ for $40 \mathrm{~h}$ in different treatment groups: (1) the untreated group (black bar), (2) 1\% (w/v) FOS (orange hollow bars), (3) $2 \%(w / v)$ FOS (slash orange bars), (4) 4\% (w/v) FOS (orange bars), (5) L. plantarum supplementation group (dark gray bars), (6) L. plantarum $+1 \%(w / v)$ FOS (blue hollow bars), (7) L. plantarum $+2 \%(w / v)$ FOS (slash blue bars), (8) L. plantarum $+4 \%(w / v)$ FOS (blue bars). Values are mean $\pm \operatorname{SD}(n=6)$. At each temperature, different lowercase letters $(\mathrm{a}, \mathrm{b}, \mathrm{c}, \mathrm{d}$, and e) indicate significant differences $(p<0.05)$ among treatments. 


\section{Discussion}

In the present study, we examined the single and combined effect of FOS and $L$. plantarum on the growth and in vitro virulence of $L$. monocytogenes. We observed that $L$. plantarum alone or FOS $+L$. plantarum effectively reduced the growth of $L$. monocytogenes during storage at $10^{\circ} \mathrm{C}$ and $25^{\circ} \mathrm{C}$. Furthermore, the FOS, L. plantarum, or FOS + L. plantarum treatment also decreased the invasion of L. monocytogenes to Caco-2 and BeWo cells, and down-regulated the expression levels of the $\operatorname{inl} A$, inlB, $h l y, a c t A$, sig $B$, and $\operatorname{prf} A$ genes of $L$. monocytogenes, which play key roles in the infection process of $L$. monocytogenes.

In this study, $10^{\circ} \mathrm{C}$ and $25^{\circ} \mathrm{C}$ simulated the room or refrigerated temperature at which food is processed and stored. The growth of L. monocytogenes at $37^{\circ} \mathrm{C}$ was also investigated (data not shown); there was no difference between treatment groups. We consider that this is because $37^{\circ} \mathrm{C}$ is the most suitable temperature for the growth of L. monocytogenes; therefore, addition changes have little effect on its growth at $37^{\circ} \mathrm{C}$. Thus, in this study, we set the process that food contaminated with L. monocytogenes was placed at $10^{\circ} \mathrm{C}$ and $25^{\circ} \mathrm{C}$ for a period, and ingested by a human, followed by L. monocytogenes infecting host cells at $37^{\circ} \mathrm{C}$.

Probiotics can inactivate pathogens via several mechanisms, including the production of antimicrobial substances, competition of nutrients, and cell-to-cell contact $[57,58]$. According to the strain instruction manual, the strain L. plantarum CICC 6257 used in this study is recommended as a probiotic and has an inhibitory effect against several bacteria. However, no related report introduces its probiotic function and antibacterial effect in vivo or in vitro. We did not investigate the in vivo probiotic activity of this strain, while our previous studies reported its in vitro inhibitory effect on L. monocytogenes in ground pork $[9,15]$. Except for the strain L. plantarum CICC 6257, the other Lacticaseibacillus rhamnosus strain was used but did not show an inhibitory effect against L. monocytogenes (data not shown). Thus, in this study, only this strain L. plantarum CICC 6257 was selected for exploring an inhibitory effect against $L$. monocytogenes in the simulated food substrate. In the future, it is necessary to compare more different probiotic strains to validate our results.

Our study showed that the co-culture of L. plantarum caused the L. monocytogenes concentration to decrease over $2 \log _{10} \mathrm{CFU} / \mathrm{mL}$. The growth of $L$. monocytogenes was reduced only when L. plantarum accumulated to enough concentration $\left(>8 \log _{10} \mathrm{CFU} / \mathrm{mL}\right)$ at $10{ }^{\circ} \mathrm{C}$ and $25^{\circ} \mathrm{C}$. Similar results have been reported, such as Lactobacillus curvatus reducing the growth of L. monocytogenes when L. curvatus reached $9 \log _{10} \mathrm{CFU} / \mathrm{mL}$ after $48 \mathrm{~h}$ at $20^{\circ} \mathrm{C}$ and 5 days at $15{ }^{\circ} \mathrm{C}$ [59]. This might be the result of nutrients competition between L. plantarum and L. monocytogenes, or attributed to inhibitory effect of metabolites (organic acids, diacetyl, hydrogen peroxide, and bacteriocins) produced by L. plantarum [60]. Schillinger et al. reported that the inhibition of L. monocytogenes was principally attributed to the antibacterial action of bacteriocins produced by Lactobacillus sake [10]. Huang et al. [14] reported bacteriocin-producing Enterococcus faecium reduced the cell counts of L. monocytogenes after 4 days at $4{ }^{\circ} \mathrm{C}$. Han et al. [61] also showed the bacteriocin-producing strain Lactococcus lactis $\mathrm{KC} 24$ reduced the cell counts of $L$. monocytogenes after $4 \mathrm{~h}$ at $35^{\circ} \mathrm{C}$. Thus, in this study the inhibitory effect of L. plantarum on L. monocytogenes growth occurred at $25^{\circ} \mathrm{C}$ after $45 \mathrm{~h}$ and at $10^{\circ} \mathrm{C}$ after 18 days, which might also be associated with the accumulation of bacteriocins produced by L. plantarum in the stationary phase. The mechanism of action of L. plantarum, including products of $L$. plantarum, needs to be designed and further studied in the future. In short, when L. plantarum reached a stable phase for a time, it could inhibit the growth of L. monocytogenes.

The combination of probiotics and prebiotics methods has been adopted to achieve a better inhibitory effect on pathogens in vivo and in vitro, such as how the combination of inulin/palatinose hydrate/ $\alpha$-cyclodextrin and Lactobacillus sp. or Lactococcus sp. strains could inhibit L. monocytogenes ATCC 19117 [20]. The combination of FOS and L. brevis KU200019 more effectively inhibited the adherence of L. monocytogenes ATCC 15313 and Escherichia coli O157:H4 FRIK 125 to HT-29 cells than FOS alone [35]. The combined treatment of chitosan and Pediococcus acidilactici was also found to inhibit the growth of $L$. 
monocytogenes in meatballs better than the single treatment by Incili et al. [62]. Similar to these previous reports, we also found that L. plantarum combined with $4 \%$ FOS had the best inhibitory effect on L. monocytogenes, and the L. monocytogenes concentration was reduced over $3 \log _{10} \mathrm{CFU} / \mathrm{mL}$ at $25^{\circ} \mathrm{C}$ for $45 \mathrm{~h}$ and $10{ }^{\circ} \mathrm{C}$ for 18 days. In short, the combined use of FOS and L. plantarum is more effective against L. monocytogenes growth than the single use.

There are conflicting conclusions about the effect of FOS on probiotics. FOS could act in different ways on probiotics [63], such as enhancing their bioactivity towards pathogens, increasing the production of bacteriocins, improving the growth rate, and decreasing the death rate $[35,56,64]$. In contrast, $\mathrm{Lu}$ et al. found that in an aerobic condition, the growth of Lactobacillus spp. and Bifidobacterium spp. strains was not promoted by FOS regardless of the carbohydrate source [64]. Our data showed that FOS did not accelerate the growth of L. plantarum (data not shown). Here, the ingredient of BHI needs to be considered. The $\mathrm{BHI}$ medium is rich in nutrients and contains beef heart extract, proteose peptone, glucose, sodium chloride, and disodium phosphate, all of which affect the growth and virulence of bacteria. We speculated L. plantarum preferentially used glucose of the BHI medium as a carbon source, and did not use FOS efficiently, and thus FOS did not promote the growth of L. plantarum. The investigation using other medium without carbon sources also need to be carried out in the future. Therefore, we speculate that the combined effect of FOS and L. plantarum against L. monocytogenes in the BHI culture system might not be due to the promotion of FOS to L. plantarum, but due to the additional inhibitory effect of FOS and L. plantarum.

Furthermore, it is worth noting that the BHI medium does not simulate any kind of food. The actual food system is often complicated due to differences and inconsistencies in food ingredients and background bacteria; however, the BHI medium is fixed and repeatable in composition and ideal for the growth of both L. plantarum and L. monocytogenes. Commercial mediums are used in many bacteriostatic or bactericidal studies $[34,35,65]$. Thus, in this study, the BHI medium as a testing substrate was used to judge the role of FOS and L. plantarum and ensure the repeatability of the experiment. The results in the BHI medium will provide a reference for performing a similar study on real food in the future.

Moreover, compared with the FOS and L. plantarum combined treatment, the treatment of FOS alone showed a relatively weaker inhibitory effect on the growth, adhesion, invasion, and virulence of gene expressions. Even so, considering FOS could be used as sugar substitutes and is easy to operate, it may be a better choice than the FOS and L. plantarum combination for controlling the L. monocytogenes in actual food production. The $4 \%$ FOS showed a reduction of $2 \log _{10} \mathrm{CFU} / \mathrm{mL}$ compared with the control group at $10{ }^{\circ} \mathrm{C}$. The inhibitory effect of the $4 \%$ FOS is similar to that of epsilon-polylysine [66] and nisin [65,67], which have been widely used as biological bacteriostatic agents in food. It is important to investigate the effect of FOS in real food in the future.

The adhesion and invasion abilities of the L. monocytogenes to host cells were investigated. The adhesion and invasion abilities of L. monocytogenes to Caco-2 cells are reduced when L. monocytogenes is co-cultured with Lactobacillus spp. [68], Lactobacillus rhamnoides [69], and L. plantarum [55]. Moroni et al. observed that the adhesion and invasion ability of L. monocytogenes to colonocytes was reduced by Lactobacillus [70]. Similarly, our results showed that supplementation of L. plantarum significantly reduced the invasion of L. monocytogenes to Caco-2 cells, although it did not change its adhesion. Only the $4 \%$ FOS combined with L. plantarum significantly $(p<0.05)$ inhibited the adhesion of $L$. monocytogenes to Caco-2 at $25^{\circ} \mathrm{C}$, but not at $10^{\circ} \mathrm{C}$. Chen et al. reported that human milk oligosaccharide treatment reduced the infection rate of L. monocytogenes to Caco- 2 cells by $50 \%$ [71]. The FOS or L. plantarum treatment did not change the adhesion of L. monocytogenes to Caco-2 cells; however, its invasion ability was significantly lowered by more than $90 \%$. These results showed that FOS, L. plantarum, or their combination effectively prevent $L$. monocytogenes from invading intestinal barrier.

Pregnant women are a susceptible subgroup of L. monocytogenes due to the adaptability, capacity to cross various host barriers, and unique intracellular lifestyle of L. monocyto- 
genes [36], and possible exacerbation of critical immune tolerance mechanisms at the maternal-fetal interface in late pregnancy [72]. The BeWo cell line has been considered a useful in vitro placental barrier model for studying adhesion, infection [73], and transport [40]. Faralla et al. reported that in pregnant guinea pigs and mice, the virulence factor action endows $L$. monocytogenes with a strong invasion tendency to the placenta, but $L$. monocytogenes has little influence on other organs [74]. Our research confirmed this view and showed that L. monocytogenes had a higher adhesion and invasion ability to BeWo cells than Caco-2 cells. In addition, different from the result in Caco-2 cells, FOS, L. plantarum, or their combination displayed a stronger inhibited ability in both adhesion and invasion to BeWo cells. This is because L. monocytogenes infects Caco-2 and BeWo cells based on different infection mechanisms, for example, the virulence protein of L. monocytogenes acts on different acceptor proteins of the two cell lines [36]. Moreover, L. monocytogenes could destroy the barrier and enter into the host cells. The phase-contrast images of cells in the different treatment groups were observed; however, the difference among these images was not found (data not shown). In the future, to explore if L. monocytogenes influences the barrier function of host cells based on different FOS and L. plantarum treatments, immunofluorescent staining images or the related gene expression of the barrier protein are needed. Moreover, Caco-2 and BeWo cells are in vitro models, in vivo validation needs to be performed in the future. Based on these in vitro results, it could be inferred that FOS and L. plantarum might be useful for reducing the virulence of L. monocytogenes.

L. monocytogenes infection involves many virulence factors [72]. It can be internalized into host cells under the regulation of $i n l A$ and inlB [50]. Our data on the transcriptional profile of L. monocytogenes indicated that after 14 days at $10^{\circ} \mathrm{C}$ and $40 \mathrm{~h}$ at $25^{\circ} \mathrm{C}$, inlA and inlB genes were down-regulated by co-treatment with L. plantarum and FOS, suggesting that the internalization of L. monocytogenes into host cells was reduced. This also explained the possible reasons for the decrease of the invasion ability of L. monocytogenes to Caco-2 and BeWo cells after the co-treatment of L. plantarum and FOS. After L. monocytogenes enters into the host cell, $h l y$ helps to accelerate L. monocytogenes escaping from phagocytic cells [75]. Tanner et al. reported that Bifidobacterium thermophilum RBL67 decreased the expression of the hly gene in L. monocytogenes [76]. Like the previous results, the L. plantarum and FOS treatment also significantly reduced $h l y$ gene expression. Moreover, we further evaluated the relative expression of $\operatorname{prf} A$, which could activate the expression of $i n l A, i n l B, h l y$, and other essential virulence genes in the LIPI1 cluster gene products and major internalins [77]. Our previous study showed that the $\operatorname{prfA}$ gene expression was reduced using L. plantarum combined with $\mathrm{CO}_{2}$ treatment [15]. Similarly, FOS, L. plantarum, and their combined treatment also down-regulated the expression of the $\operatorname{prf} A$ gene. Another virulence factor, act $A$, plays an important role in the capacity of the L. monocytogenes to polymerize actin and spread from cell to cell [52]. An important role of $i n l A$, inlB, and act $A$ in the process of invasion through the placental syncytiotrophoblast layer has been shown in human placental explants and animal models [36]. Thus, it is suggested that after the treatment of $L$. plantarum and FOS, the down-regulation of $i n l A$, inlB, and act $A$ expression may contribute to the reduction of L. monocytogenes adhesion and invasion to BeWo cells. Furthermore, $\operatorname{sig} B$ plays a vital role in the infectious cycle of $L$. monocytogenes, including regulating inl $A$ and $i n l B$, and down-regulating flagellum production before internalization [78]. Based on these discussions, under the FOS or L. plantarum treatment, the inhibition of the invasion process of L. monocytogenes to Caco-2 and BeWo cells was attributed to the down-regulation of inlA, inlB, sigB, hly, act $A$, and PrfA expression.

\section{Conclusions}

This study demonstrated that the presence of L. plantarum and FOS in the medium could reduce the pathogenic potential of L. monocytogenes by inhibiting the growth, decreasing the capability to adhesion and invasion of Caco-2 and BeWo cells, and down-regulating the virulence genes expression. The strain of L. plantarum can be used as a protective culture to inhibit L. monocytogenes. L. plantarum combined with FOS had a stronger ability than 
L. plantarum or FOS individually to reduce the pathogenic potential of L. monocytogenes. Specifically, L. plantarum combined with $2 \%$ or $4 \%$ FOS had the most obvious inhibitory effect on L. monocytogenes. However, there are some future directions to use and apply this technique in food to know the real food substrate as well to design an in vivo study to validate the current findings related to virulent genes.

Author Contributions: Conceptualization, X.L. and Q.D.; methodology, X.L. and B.G.; software, X.L. and Y.L.; validation, Q.D. and X.W.; formal analysis, X.L.; investigation, X.L.; resources, Z.L. and Q.D.; data curation, X.L.; writing-original draft preparation, X.L. and Z.L.; writing-review and editing, M.Z.A., Z.L. and Q.D.; visualization, X.L.; supervision, Q.D. and Z.L.; project administration, Q.D. and Z.L.; funding acquisition, Q.D. All authors have read and agreed to the published version of the manuscript.

Funding: This work was supported by Key Projects of International Scientific and Technological Innovation Cooperation Among Governments Under National Key R\&D Plan [2019YFE0103800].

Institutional Review Board Statement: Not applicable.

Informed Consent Statement: Not applicable.

Data Availability Statement: All data related to the research are presented in the article.

Acknowledgments: We thank Leon G.M. Gorris in the Netherlands for his support and valuable suggestions.

Conflicts of Interest: The authors declare no conflict of interest.

\section{References}

1. Gandhi, M.; Chikindas, M.L. Listeria: A foodborne pathogen that knows how to survive. Int. J. Food Microbiol. 2007, 113, 1-15. [CrossRef]

2. Oloketuyi, S.F.; Khan, F. Inhibition strategies of Listeria monocytogenes biofilms-current knowledge and future outlooks. J. Basic. Microbiol. 2017, 57, 728-743. [CrossRef]

3. Thomas, J.; Govender, N.; McCarthy, K.M.; Erasmus, L.K.; Doyle, T.J.; Allam, M.; Ismail, A.; Ramalwa, N.; Sekwadi, P.; Ntshoe, G.; et al. Outbreak of Listeriosis in South Africa Associated with Processed Meat. N. Engl. J. Med. 2020, 382, 632-643. [CrossRef] [PubMed]

4. Desai, A.N.; Anyoha, A.; Madoff, L.C.; Lassmann, B. Changing epidemiology of Listeria monocytogenes outbreaks, sporadic cases, and recalls globally: A review of ProMED reports from 1996 to 2018. Int. J. Infect Dis. 2019, 84, 48-53. [CrossRef] [PubMed]

5. Salminen, S.; Laine, M.; Wright, A.V.; Vuopio-Varkila, J.; Korhonen, T.; Matila-Sandh, T.M. Development Potential of Selection Criteria in Functional for Probiotic Strains to Assess Their Foods: A Nordic and European Approach. Biosci. Microflora 1996, 15, 61-67. [CrossRef]

6. $\quad$ Bukvicki, D.; Siroli, L.; D'Alessandro, M.; Cosentino, S.; Fliss, I.; Said, L.B.; Hassan, H.; Lanciotti, R.; Patrignani, F. Unravelling the Potential of Lactococcus lactis Strains to Be Used in Cheesemaking Production as Biocontrol Agents. Foods 2020, 9, 1815. [CrossRef]

7. Park, K.M.; Yoon, S.G.; Choi, T.H.; Kim, H.J.; Park, K.J.; Koo, M. The Bactericidal Effect of a Combination of Food-Grade Compounds and their Application as Alternative Antibacterial Agents for Food Contact Surfaces. Foods 2020, 9, 59. [CrossRef]

8. Kamiloğlu, A.; Kaban, G.; Kaya, M. Effects of autochthonous Lactobacillus plantarum strains on Listeria monocytogenes in sucuk during ripening. J. Food Saf. 2019, 39. [CrossRef]

9. Zhang, W.; Wang, X.; Xu, C.; Chen, Y.; Sun, W.; Liu, Q.; Dong, Q. Modeling inhibition effects of Lactobacillus plantarum subsp. plantarum CICC 6257 on growth of Listeria monocytogenes in ground pork stored at $\mathrm{CO}_{2}$-rich atmospheres. LWT-Food Sci. Technol. 2018, 97, 811-817. [CrossRef]

10. Schillinger, U.; Kaya, M.; Lücke, F.K. Behaviour of Listerla monocytogenes in meat and its control by a bacteriocin-producing strain of Lactobacillus sake. J. Appl. Bacteriol. 1991, 70, 473-478. [CrossRef] [PubMed]

11. RodríGuez, E.V.A.; Arqués, J.L.; Gaya, P.; Nuñez, M.; Medina, M. Control of Listeria monocytogenes by bacteriocins and monitoring of bacteriocin-producing lactic acid bacteria by colony hybridization in semi-hard raw milk cheese. J. Dairy Res. 2001, 68, 131-137. [CrossRef]

12. Aljasir, S.F.; Gensler, C.; Sun, L.; D'Amico, D.J. The efficacy of individual and combined commercial protective cultures against Listeria monocytogenes, Salmonella, $\mathrm{O} 157$ and non-O157 shiga toxin-producing Escherichia coli in growth medium and raw milk. Food Control 2020, 109, 106924. [CrossRef]

13. Beristain-Bauza, S.C.; Mani-López, E.; Palou, E.; López-Malo, A. Antimicrobial activity and physical properties of protein films added with cell-free supernatant of Lactobacillus rhamnosus. Food Control 2016, 62, 44-51. [CrossRef]

14. Huang, Y.; Ye, K.; Yu, K.; Wang, K.; Zhou, G. The potential influence of two Enterococcus faecium on the growth of Listeria monocytogenes. Food Control 2016, 67, 18-24. [CrossRef] 
15. Dong, Q.; Zhang, W.; Guo, L.; Niu, H.; Liu, Q.; Wang, X. Influence of Lactobacillus plantarum individually and in combination with low $\mathrm{O}_{2}$-MAP on the pathogenic potential of Listeria monocytogenes in cabbage. Food Control 2020, 107, 106765. [CrossRef]

16. Upadhyay, A.; Upadhyaya, I.; Mooyottu, S.; Venkitanarayanan, K. Eugenol in combination with lactic acid bacteria attenuates Listeria monocytogenes virulence in vitro and in invertebrate model Galleria mellonella. J. Med. Microbiol. 2016, 65, 443-455. [CrossRef]

17. Salminen, S.; Collado, M.C.; Endo, A.; Hill, C.; Lebeer, S.; Quigley, E.M.M.; Sanders, M.E.; Shamir, R.; Swann, J.R.; Szajewska, H.; et al. The International Scientific Association of Probiotics and Prebiotics (ISAPP) consensus statement on the definition and scope of postbiotics. Nat. Rev. Gastroenterol. Hepatol. 2021, 18, 649-667. [CrossRef]

18. Speranza, B.; Campaniello, D.; Monacis, N.; Bevilacqua, A.; Sinigaglia, M.; Corbo, M.R. Functional cream cheese supplemented with Bifidobacterium animalis subsp. lactis DSM 10140 and Lactobacillus reuteri DSM 20016 and prebiotics. Food Microbiol. 2018, 72, 16-22. [CrossRef] [PubMed]

19. Adebola, O.O.; Corcoran, O.; Morgan, W.A. Synbiotics: The impact of potential prebiotics inulin, lactulose and lactobionic acid on the survival and growth of lactobacilli probiotics. J. Funct. Foods 2014, 10, 75-84. [CrossRef]

20. Pranckute, R.; Kaunietis, A.; Kuisiene, N.; Citavicius, D.J. Combining prebiotics with probiotic bacteria can enhance bacterial growth and secretion of bacteriocins. Int. J. Biol. Macromol. 2016, 89, 669-676. [CrossRef] [PubMed]

21. Bengoa, A.A.; Dardis, C.; Garrote, G.L.; Abraham, A.G. Health-Promoting Properties of Lacticaseibacillus paracasei: A Focus on Kefir Isolates and Exopolysaccharide-Producing Strains. Foods 2021, 10, 2239. [CrossRef]

22. Mutanda, T.; Mokoena, M.P.; Olaniran, A.O.; Wilhelmi, B.S.; Whiteley, C.G. Microbial enzymatic production and applications of short-chain fructooligosaccharides and inulooligosaccharides: Recent advances and current perspectives. J. Ind. Microbiol. Biotechnol. 2014, 41, 893-906. [CrossRef]

23. Sabater-Molina, M.; Larque, E.; Torrella, F.; Zamora, S. Dietary fructooligosaccharides and potential benefits on health. J. Physiol. Biochem. 2009, 65, 315-328. [CrossRef]

24. Jovanovic-Malinovska, R.; Kuzmanova, S.; Winkelhausen, E. Oligosaccharide Profile in Fruits and Vegetables as Sources of Prebiotics and Functional Foods. Int. J. Food Prop. 2014, 17, 949-965. [CrossRef]

25. Chow, J. Probiotics and prebiotics: A brief overview. J. Ren. Nutr. 2002, 12, 76-86. [CrossRef] [PubMed]

26. Liu, F.; Li, P.; Chen, M.; Luo, Y.; Prabhakar, M.; Zheng, H.; He, Y.; Qi, Q.; Long, H.; Zhang, Y.; et al. Fructooligosaccharide (FOS) and Galactooligosaccharide (GOS) Increase Bifidobacterium but Reduce Butyrate Producing Bacteria with Adverse Glycemic Metabolism in healthy young population. Sci. Rep. 2017, 7, 11789. [CrossRef] [PubMed]

27. Cherbut, C.; Michel, C.; Lecannu, G. The prebiotic characteristics of fructooligosaccharides are necessary for reduction of TNBS-induced colitis in rats. J. Nur. 2003, 133, 21-27. [CrossRef] [PubMed]

28. Lee, H.-W.; Park, Y.-S.; Jung, J.-S.; Shin, W.-S. Chitosan oligosaccharides, dp 2-8, have prebiotic effect on the Bifidobacterium bifidium and Lactobacillus sp. Anaerobe 2002, 8, 319-324. [CrossRef]

29. Ding, S.; Wang, Y.; Yan, W.; Li, A.; Jiang, H.; Fang, J. Effects of Lactobacillus plantarum 15-1 and fructooligosaccharides on the response of broilers to pathogenic Escherichia coli O78 challenge. PLoS ONE 2019, 14, e0212079. [CrossRef]

30. Rubio-Gomez, J.M.; Santiago, C.M.; Udaondo, Z.; Garitaonaindia, M.T.; Krell, T.; Ramos, J.L.; Daddaoua, A. Full Transcriptomic Response of Pseudomonas aeruginosa to an Inulin-Derived Fructooligosaccharide. Front. Microbiol. 2020, 11, 202. [CrossRef]

31. De Figueiredo, F.C.; de Barros Ranke, F.F.; de Oliva-Neto, P. Evaluation of xylooligosaccharides and fructooligosaccharides on digestive enzymes hydrolysis and as a nutrient for different probiotics and Salmonella typhimurium. LWT-Food Sci. Technol. 2020, 118, 108761. [CrossRef]

32. Piotrowski, M.; Wultanska, D.; Obuch-Woszczatynski, P.; Pituch, H. Fructooligosaccharides and mannose affect Clostridium difficile adhesion and biofilm formation in a concentration-dependent manner. Eur. J. Clin. Microbiol. Infect Dis. 2019, 38, 1975-1984. [CrossRef]

33. Sharma, S.; Kanwar, S.S. Effect of prebiotics on growth behavior of Lactobacillus plantarum and their impact on adherence of strict anaerobic pathogens to intestinal cell lines. J. Food Saf. 2017, 38, e12384. [CrossRef]

34. Anand, S.; Mandal, S.; Singh, K.S.; Patil, P.; Tomar, S.K. Synbiotic combination of Lactobacillus rhamnosus NCDC 298 and short chain fructooligosaccharides prevents enterotoxigenic Escherichia coli infection. LWT-Food Sci. Technol. 2018, 98, 329-334. [CrossRef]

35. Kariyawasam, K.; Yang, S.J.; Lee, N.K.; Paik, H.D. Probiotic Properties of Lactobacillus brevis KU200019 and Synergistic Activity with Fructooligosaccharides in Antagonistic Activity against Foodborne Pathogens. Food Sci. Anim. Resour. 2020, 40, 297-310. [CrossRef]

36. Radoshevich, L.; Cossart, P. Listeria monocytogenes: Towards a complete picture of its physiology and pathogenesis. Nat. Rev. Microbiol. 2018, 16, 32-46. [CrossRef]

37. Pereira, M.G.; de Almeida, O.G.G.; da Silva, H.R.A.; Ishizawa, M.H.; De Martinis, E.C.P. Studies on host-foodborne bacteria in intestinal three-dimensional cell culture model indicate possible mechanisms of interaction. World J. Microbiol. Biotechnol. 2021, 37, 31. [CrossRef] [PubMed]

38. Ding, X.; Hu, X.; Chen, Y.; Xie, J.; Ying, M.; Wang, Y.; Yu, Q. Differentiated Caco-2 cell models in food-intestine interaction study: Current applications and future trends. Trends Food Sci. Technol. 2021, 107, 455-465. [CrossRef]

39. Gagnon, M.; Zihler Berner, A.; Chervet, N.; Chassard, C.; Lacroix, C. Comparison of the Caco-2, HT-29 and the mucus-secreting HT29-MTX intestinal cell models to investigate Salmonella adhesion and invasion. J. Microbiol. Methods 2013, 94, 274-279. [CrossRef] 
40. Li, Z.; Kurosawa, O.; Iwata, H. A comparative study of key physiological stem cell parameters between three human trophoblast cell lines. Biochem. Biophys. Res. Commun. 2020, 525, 1038-1045. [CrossRef] [PubMed]

41. Li, Z.; Kurosawa, O.; Iwata, H. Establishment of human trophoblast stem cells from human induced pluripotent stem cell-derived cystic cells under micromesh culture. Stem. Cell Res. Ther. 2019, 10, 245. [CrossRef] [PubMed]

42. Ye, K.; Zhang, X.; Huang, Y.; Liu, J.; Liu, M.; Zhou, G. Bacteriocinogenic Enterococcus faecium inhibits the virulence property of Listeria monocytogenes. LWT-Food Sci. Technol. 2018, 89, 87-92. [CrossRef]

43. Mathipa, M.G.; Bhunia, A.K.; Thantsha, M.S. Internalin AB-expressing recombinant Lactobacillus casei protects Caco-2 cells from Listeria monocytogenes-induced damages under simulated intestinal conditions. PLoS ONE 2019, 14, e0220321. [CrossRef]

44. Lecuit, M.; Nelson, D.M.; Smith, S.D.; Khun, H.; Huerre, M.; Vacher-Lavenu, M.C.; Gordon, J.I.; Cossart, P. Targeting and crossing of the human maternofetal barrier by Listeria monocytogenes: Role of internalin interaction with trophoblast E-cadherin. Proc. Natl. Acad. Sci. USA 2004, 101, 6152-6157. [CrossRef]

45. Phelps, C.C.; Vadia, S.; Arnett, E.; Tan, Y.; Zhang, X.; Pathak-Sharma, S.; Gavrilin, M.A.; Seveau, S. Relative Roles of Listeriolysin $\mathrm{O}$, InlA, and InlB in Listeria monocytogenes Uptake by Host Cells. Infect. Immun. 2018, 86, e00555-18. [CrossRef]

46. Bakardjiev, A.I.; Stacy, B.A.; Fisher, S.J.; Portnoy, D.A. Listeriosis in the pregnant guinea pig: A model of vertical transmission. Infect. Immun. 2004, 72, 489-497. [CrossRef]

47. Tsai, Y.H.; Disson, O.; Bierne, H.; Lecuit, M. Murinization of internalin extends its receptor repertoire, altering Listeria monocytogenes cell tropism and host responses. PLoS Pathog 2013, 9, e1003381. [CrossRef]

48. Wollert, T.; Pasche, B.; Rochon, M.; Deppenmeier, S.; van den Heuvel, J.; Gruber, A.D.; Heinz, D.W.; Lengeling, A.; Schubert, W.D. Extending the host range of Listeria monocytogenes by rational protein design. Cell 2007, 129, 891-902. [CrossRef]

49. Saá Ibusquiza, P.; Nierop Groot, M.; Debán-Valles, A.; Abee, T.; den Besten, H.M.W. Impact of growth conditions and role of sigB on Listeria monocytogenes fitness in single and mixed biofilms cultured with Lactobacillus plantarum. Food Res. Int. 2015, 71, 140-145. [CrossRef]

50. Buchanan, R.L.; Gorris, L.G.M.; Hayman, M.M.; Jackson, T.C.; Whiting, R.C. A review of Listeria monocytogenes: An update on outbreaks, virulence, dose-response, ecology, and risk assessments. Food Control 2017, 75, 1-13. [CrossRef]

51. Rios-Covian, D.; Nogacka, A.; Salazar, N.; Hernandez-Barranco, A.M.; Cuesta, I.; Gueimonde, M.; de Los Reyes Gavilan, C.G. Bifidobacterium breve IPLA20005 affects in vitro the expression of hly and luxS genes, related to the virulence of Listeria monocytogenes Lm23. Can. J. Microbiol. 2018, 64, 215-221. [CrossRef]

52. Olesen, I.; Vogensen, F.K.; Jespersen, L. Gene Transcription and Virulence Potential of Listeria monocytogenes Strains after Exposure to Acidic and $\mathrm{NaCl}$ Stress. Foodborne Pathog. Dis. 2009, 6, 669-680. [CrossRef]

53. Kariyawasam, K.M.G.M.M.; Lee, N.-K.; Paik, H.-D. Synbiotic yoghurt supplemented with novel probiotic Lactobacillus brevis KU200019 and fructooligosaccharides. Food Biosci. 2021, 39, 100835. [CrossRef]

54. Zilelidou, E.A.; Rychli, K.; Manthou, E.; Ciolacu, L.; Wagner, M.; Skandamis, P.N. Highly Invasive Listeria monocytogenes Strains Have Growth and Invasion Advantages in Strain Competition. PLoS ONE 2015, 10, e0141617. [CrossRef] [PubMed]

55. Zilelidou, E.A.; Milina, V.; Paramithiotis, S.; Zoumpopoulou, G.; Poimenidou, S.V.; Mavrogonatou, E.; Kletsas, D.; Papadimitriou, K.; Tsakalidou, E.; Skandamis, P.N. Differential Modulation of Listeria monocytogenes Fitness, In Vitro Virulence, and Transcription of Virulence-Associated Genes in Response to the Presence of Different Microorganisms. Food Microbiol. 2020, 86, e01165-20. [CrossRef] [PubMed]

56. Livak, K.J.; Schmittgen, T.D. Analysis of relative gene expression data using real-time quantitative PCR and the 2(-Delta Delta C(T)) Method. Methods 2001, 25, 402-408. [CrossRef] [PubMed]

57. Miranda, R.O.; Campos-Galvao, M.E.M.; Nero, L.A. Expression of genes associated with stress conditions by Listeria monocytogenes in interaction with nisin producer Lactococcus lactis. Food Res. Int. 2018, 105, 897-904. [CrossRef]

58. Saraoui, T.; Fall, P.A.; Leroi, F.; Antignac, J.P.; Chereau, S.; Pilet, M.F. Inhibition mechanism of Listeria monocytogenes by a bioprotective bacteria Lactococcus piscium CNCM I-4031. Food Microbiol. 2016, 53, 70-78. [CrossRef]

59. Giello, M.; La Storia, A.; De Filippis, F.; Ercolini, D.; Villani, F. Impact of Lactobacillus curvatus $54 \mathrm{M} 16$ on microbiota composition and growth of Listeria monocytogenes in fermented sausages. Food Microbiol. 2018, 72, 1-15. [CrossRef]

60. Cornu, M.; Billoir, E.; Bergis, H.; Beaufort, A.; Zuliani, V. Modeling microbial competition in food: Application to the behavior of Listeria monocytogenes and lactic acid flora in pork meat products. Food Microbiol. 2011, 28, 639-647. [CrossRef]

61. Han, E.J.; Lee, N.K.; Choi, S.Y.; Paik, H.D. Short communication: Bacteriocin KC24 produced by Lactococcus lactis KC24 from kimchi and its antilisterial effect in UHT milk. J. Dairy Sci. 2013, 96, 101-104. [CrossRef] [PubMed]

62. İncili, G.K.; Karatepe, P.; İlhak, O.İ. Effect of chitosan and Pediococcus acidilactici on E. coli O157:H7, Salmonella Typhimurium and Listeria monocytogenes in meatballs. LWT-Food Sci. Technol. 2020, 117, 108706. [CrossRef]

63. Bevilacqua, A.; Corbo, M.R.; Sinigaglia, M.; Speranza, B.; Campaniello, D.; Altieri, C. Effects of inulin, fructooligosaccharides/glucose and $\mathrm{pH}$ on the shape of the death kinetic of Lactobacillus reuteri DSM 20016. Int. J. Food Sci. Technol. 2016, 51, 2251-2259. [CrossRef]

64. Lu, E.; Yeung, M.; Yeung, C.K. Comparative Analysis of Lactulose and Fructooligosaccharide on Growth Kinetics, Fermentation, and Antioxidant Activity of Common Probiotics. Food Nutr. Sci. 2018, 09, 161-178. [CrossRef]

65. Ibarra-Sanchez, L.A.; Kong, W.; Lu, T.; Miller, M.J. Efficacy of nisin derivatives with improved biochemical characteristics, alone and in combination with endolysin PlyP100 to control Listeria monocytogenes in laboratory-scale Queso Fresco. Food Microbiol. 2021, 94, 103668. [CrossRef] 
66. Chang, S.S.; Lu, W.Y.; Park, S.H.; Kang, D.H. Control of foodborne pathogens on ready-to-eat roast beef slurry by epsilonpolylysine. Int. J. Food Microbiol. 2010, 141, 236-241. [CrossRef]

67. Heir, E.; Solberg, L.E.; Carlehog, M.; Moen, B.; Jensen, M.R.; Holck, A.L. Improved control of Listeria monocytogenes during storage of raw salmon by treatment with the fermentate Verdad N6 and nisin. Int. J. Food Microbiol. 2021, 336, 108895. [CrossRef]

68. Castellano, P.; Pérez Ibarreche, M.; Longo Borges, L.; Niño Arias, F.C.; Ross, G.R.; De Martinis, E.C.P. Lactobacillus spp. impair the ability of Listeria monocytogenes FBUNT to adhere to and invade Caco-2 cells. Biotechnol. Lett. 2018, 40, 1237-1244. [CrossRef]

69. Iglesias, M.B.; Viñas, I.; Colás-Medà, P.; Collazo, C.; Serrano, J.C.E.; Abadias, M. Adhesion and invasion of Listeria monocytogenes and interaction with Lactobacillus rhamnosus GG after habituation on fresh-cut pear. J. Funct. Foods 2017, 34, 453-460. [CrossRef]

70. Moroni, O.; Kheadr, E.; Boutin, Y.; Lacroix, C.; Fliss, I. Inactivation of adhesion and invasion of food-borne Listeria monocytogenes by bacteriocin-producing Bifidobacterium strains of human origin. Appl. Environ. Microbiol. 2006, 72, 6894-6901. [CrossRef]

71. Chen, P.; Reiter, T.; Huang, B.; Kong, N.; Weimer, B.C. Prebiotic Oligosaccharides Potentiate Host Protective Responses against L. Monocytogenes Infection. Pathogens 2017, 6, 68. [CrossRef]

72. Vazquez-Boland, J.A.; Krypotou, E.; Scortti, M. Listeria Placental Infection. MBio 2017, 8, e00949-17. [CrossRef]

73. Rothbauer, M.; Patel, N.; Gondola, H.; Siwetz, M.; Huppertz, B.; Ertl, P. A comparative study of five physiological key parameters between four different human trophoblast-derived cell lines. Sci. Rep. 2017, 7, 5892. [CrossRef]

74. Faralla, C.; Rizzuto, G.A.; Lowe, D.E.; Kim, B.; Cooke, C.; Shiow, L.R.; Bakardjiev, A.I. InlP, a New Virulence Factor with Strong Placental Tropism. Infect. Immun. 2016, 84, 3584-3596. [CrossRef]

75. Hadjilouka, A.; Molfeta, C.; Panagiotopoulou, O.; Paramithiotis, S.; Mataragas, M.; Drosinos, E.H. Expression of Listeria monocytogenes key virulence genes during growth in liquid medium, on rocket and melon at 4, 10 and 30 degrees C. Food Microbiol. 2016, 55, 7-15. [CrossRef]

76. Tanner, S.A.; Chassard, C.; Rigozzi, E.; Lacroix, C.; Stevens, M.J. Bifidobacterium thermophilum RBL67 impacts on growth and virulence gene expression of Salmonella enterica subsp. enterica serovar Typhimurium. BMC Microbiol. 2016, 16, 46. [CrossRef] [PubMed]

77. Fang, C.; Cao, T.; Cheng, C.; Xia, Y.; Shan, Y.; Xin, Y.; Guo, N.; Li, X.; Song, H.; Fang, W. Activation of PrfA results in overexpression of virulence factors but does not rescue the pathogenicity of Listeria monocytogenes M7. J. Med. Microbiol. 2015, 64, 818-827. [CrossRef] [PubMed]

78. Gaballa, A.; Guariglia-Oropeza, V.; Wiedmann, M.; Boor, K.J. Cross Talk between SigB and PrfA in Listeria monocytogenes Facilitates Transitions between Extra- and Intracellular Environments. Microbiol. Mol. Biol. Rev. 2019, 83, e00034-19. [CrossRef] [PubMed] 